\title{
Influence of Different Levels of Phosphorus on the Effectiveness of Arbuscular Mycorrhizae in Rice Rhizosphere
}

\author{
Ipsita Ojah $^{1}$ *, Dhruba Jyoti Nath ${ }^{2}$, Anjuma Gayan ${ }^{3}$ and Smrita Buragohain ${ }^{1}$ \\ ${ }^{1}$ Department of Soil Science, Assam Agricultural University, Jorhat-785013, India \\ ${ }^{2}$ AINP on Soil Biodiversity-Biofertilizers, Department of Soil Science, Assam Agricultural \\ University, Jorhat-785013, India \\ ${ }^{3}$ College of Sericulture, Assam Agricultural University, Jorhat-785013,
}

*Corresponding author

\section{A B S T R A C T}

Keywords

Arbuscular

Mycorrhyzal fungi,

Spore abundance,

Root colonization,

Different doses of

phosphorus,

Phosphomonoesterase activity

Article Info

Accepted:

08 June 2018

Available Online:

10 July 2018
Arbuscular Mycorrhyzae Fungal (AMF) spores were obtained through mass multiplication in maize (in a previous experiment) as a host crop. A study was conducted to test the effectiveness of AMF in rice as host, with three levels of $\mathrm{P}_{2} \mathrm{O}_{5}(0,20$ and $40 \mathrm{~kg} / \mathrm{ha})$ under submerged condition. By reducing levels of $\mathrm{P}_{2} \mathrm{O}_{5}$ to $50 \%(20 \mathrm{~kg} / \mathrm{ha})$ comparable plant biomasses were recorded $(\mathrm{P}<0.05)$ under AMF inoculation with that of highest level of $\mathrm{P}_{2} \mathrm{O}_{5}(40 \mathrm{~kg} / \mathrm{ha})$ with or without AMF inoculation. By reducing the $\mathrm{P}$ supply $(20 \mathrm{~kg} / \mathrm{ha})$, measurable effect of mycorrhyzae $(\mathrm{P}<0.05)$ was obtained for $\mathrm{P}$ and $\mathrm{N}$ concentration $(1.27$ and $7.88 \mathrm{mg} / \mathrm{g}$ respectively) and their uptake $(20.63$ and $127.50 \mathrm{mg} /$ plant respectively) in rice plants which were comparable with un-inoculated plants at $40 \mathrm{~kg} \mathrm{P}_{2} \mathrm{O}_{5} / \mathrm{ha}$. AMF spores and root colonization were found at all levels of $\mathrm{P}$ supply, although overall the numbers of mycorrhyzal spores and per cent root colonization decreased with increasing $\mathrm{P}$ under mycorrhyza inoculation which implies that saturation or inundation does not necessarily prevent the development of AMF association.

\section{Introduction}

Arbuscular mycorrhizal fungi (AMF) are soil inhabitants belonging to phylum, Glomeromycota (Sturmer, 2012) which forms symbiotic association with plants. The association allows an alternative nutrient assimilation pathway for plants through its special structures viz: extraradical and intraradical hyphae, arbuscules and the root apoplast interface. Hyphae of AMF can extend beyond the root surface i.e. extend beyond the rhizosphere nutrient-depletion zones which allows AMF to access a larger volume of soil (Smith and Read, 2008) to mobilise plant nutrients.

AMF provide benefits to their host plant in many ways, the most important being the enhanced uptake of $\mathrm{P}$ from soil, both in upland and in wet land situation (Stevens et al., 2002; Smith and Read, 2008; Smith and Smith, 2011). Koide and his co-workers in 2000 suggested that AMF plays a significant role in 
crop $\mathrm{P}$ nutrition by increasing total uptake and in some cases increase the $\mathrm{P}$ use efficiency, which may be associated with increased plant growth and yield. If the fungal colonisation is disrupted or hampered, uptake of P, growth and in some cases yield can be significantly reduced (Thompson, 1994). Besides improved P nutrition by AMF (Smith and Smith, 2011), it was reported that mycorrhizal plants can transfer $\mathrm{N}$ to the host plants, ranging from 20 to $74 \%$ of the total $\mathrm{N}$ uptake (Tanaka and Yano, 2005; Fellbaum et al., 2014) from both inorganic and organic $\mathrm{N}$ sources (Hodge et al., 2001; Leigh et al., 2009).

According to Kahiluoto and his associates in 2009, contributions of AMF to soil quality and functional capacity of soil are particularly favoured in low-input systems as compared to conventional cropping systems. In cases of high concentration of available soil $\mathrm{P}$ crops fail to respond to colonisation by native AMF as colonisation of roots by AMF is often suppressed.

When strong colonisation occurs under conditions of high soil $\mathrm{P}$ concentrations, crop growth may be reduced. With a high rate of AMF colonization in soil where $P$ availability is low, more $\mathrm{P}$ can be accessed from the soil for plants through absorption from an extensive hyphal network, thereby increasing potential uptake of other nutrients.

The importance and function of AMF associations in upland rice are well documented (Maiti et al., 2005, 2011), but not to a greater extent in case of aquatic or semiaquatic systems. However, benefits on maintaining the AMF association under wetland conditions have been suggested for rice (Solaiman and Hirata, 1997; Purakayastha and Chhonkar, 2001). These beneficial effects of $\mathrm{AMF}$ in aquatic and semiaquatic environments suggest some parallels with terrestrial systems. In the present study, the effectiveness of AMF was tested in rice
(Variety: Basundhara) with different levels of $P$ fertilization under submerged situation.

\section{Materials and Methods}

Surface field soil samples $(0-15 \mathrm{~cm})$ growing rice crop was collected from the Instructional Cum Research (ICR) farm of the Assam Agricultural University for the present study. The soils were pulverised, mixed uniformly and air dried. The initial soil chemical parameters were analysed and shown in (Table 1).

\section{The treatment details}

Three levels of $\mathrm{P}_{2} \mathrm{O}_{5}(0,20$ and $40 \mathrm{~kg} / \mathrm{ha})$ with $\left(\mathrm{M}_{1}\right)$ and without (Mo) AMF inoculation were arranged in four replications for the pot experiment. The recommended $\mathrm{N}(40 \mathrm{~kg} / \mathrm{ha})$ and $\mathrm{K}_{2} \mathrm{O}(20 \mathrm{~kg} / \mathrm{ha})$ were applied in all the treatments. Rice (Variety: Basundhara) was taken as the test crop. The experiment was laid out in a Completely Randomized Design (CRD).

\section{Planting of rice seeds}

Rice seeds were germinated in water agar. The germinated radicles were inoculated with consortia of Glomus and Gigaspora spp. belonging to AMF @ 50 spore/seedling. The pots with $\mathrm{M}_{\mathrm{o}}$ treatment were pre inoculated with chopped maize roots and adhering soils (100 g/pot). The pots were kept at saturated conditions for 60 days.

\section{Shoot and root biomass}

After 60 days of growth, the plants were uprooted and the fresh biomass of shoots and roots were determined. Portions $(50 \%)$ of the fresh roots were kept for colonization study. The remaining shoots and roots were dried in hot air oven at $105^{\circ} \mathrm{C}$ for $24 \mathrm{~h}$ for determination of dry matter. 
Isolation of AMF spores and per cent root colonization

Isolation of AM Fungal spores was carried out by wet sieving and decanting method of Gerdemann and Nicolson (1963) by using the sieves of sizes ranging from $710 \mu$ to $53 \mu$. $100 \mathrm{~g}$ fresh rhizosphere soil sample was mixed in $300 \mathrm{~mL}$ of distilled water and shaken in a mechanical shaker at $200 \mathrm{rpm}$ for $24 \mathrm{~h}$. The spores and spore clusters retained in $53 \mu$ and $100 \mu$ were washed and collected in a filter paper. The spores were separated under inverted steriozoom microscope based on their morphology. Spore abundance was expressed as the number of AM Fungal spores per 100 gram soil. The spores were then preserved in ringer solution in small vials for further characterization.

Per cent root colonization was accessed using the method of Phillips and Haymen (1970). Root samples were washed under tap water, cut into small pieces of approximately $1 \mathrm{~cm}$ and boiled in $10 \% \mathrm{KOH}$ as a clearing agent for one hour. The boiled samples were acidified with $2 \% \mathrm{HCl}$ for five minutes and subsequently warmed in $0.05 \%$ trypan blue in lacto-phenol. After pouring off the stain, lactophenol was added and kept overnight to destain the host tissues. Slides were prepared and examined under microscope for per cent root colonization

\section{Plant tissue analysis}

Plant analysis is the quantitative determination of the concentration of an element or extractable fraction of an element in a sample from a particular part or portion of a crop. In the present study, concentration of two elements viz. nitrogen $(\mathrm{N})$ and phosphorus were determined. The total $\mathrm{N}$ of the plant tissues were determined by Kjeldahl method as described by Johann Kjeldahl (1883). The total $\mathrm{P}$ of the plant tissues were determined by Vanadomolybdate method as described by
Watanabe and Olsen (1965). The uptake of nutrients was calculated by multiplying the concentration of the nutrients in the tissue samples with the corresponding yields of shoot dry weight.

Nutrients Uptake (mg/plant) $=$ shoot dry wt. $\times$ nutrient concentration

\section{Available phosphorus}

The available $\mathrm{P}_{2} \mathrm{O}_{5}$ of the soil samples were determined using Bray's-I method meant for acidic soils (Bray and Kurtz, 1956; Jackson, 1973).

\section{Enzyme phosphomonoesterase activity}

The method of Tabatabai and Bremner (1969) was followed to estimate Phosphomonoesterase (PHM) activity. It involves the use of an artificial substrate called $p$-nitrophenyl phosphate ( $p$-NPP). The product of PHM activity, $p$-nitrophenol, is a yellow chromophore under alkaline conditions were detected colorimetrically and expressed as $\mu \mathrm{g} p$-nitrophenol/g dry soil/hr.

\section{Statistical analysis}

The experimental data obtained from various observations were analysed statistically by using analysis of variance in complete randomized block design (Pot experiment) as described by Gomez and Gomez (1984). Significance or non significance of the variance due to various treatments effect was determined by calculating respective ' $F$ ' values.

The standard error of mean was calculated by using the formula:

S. Em $=\sqrt{\frac{E M S}{r}}$

The critical difference (C.D.) at 5\% probability level was calculated to find out the 
mean difference between the treatments. CD was calculated by using the following expression.

C.D. $=\mathrm{S} . \mathrm{Em} \times$ value of $\mathrm{t}(5 \%)$ for error d.f. $\times \sqrt{2}$

Where,

$\mathrm{t}=$ table value of ' $\mathrm{t}$ ' at $5 \%$ and $1 \%$ probability level for error degrees of freedom.

To validate the effectiveness among the different variables, correlation coefficient and linear regression was used and the best fit was graphically represented (Fig. 3) as scatter diagram.

\section{Results and Discussion}

Effectiveness of mass multiplied mycorrhyzal spores in rice

The pot experiment as described in the materials and methods was carried out to understand the effectiveness of the mass multiplied AMF spore in rice crop with different levels of $\mathrm{P}_{2} \mathrm{O}_{5}$. The salient findings of the pot experiment are described below.

Shoot and root biomass as influenced by levels of $\mathrm{P}_{2} \mathrm{O}_{5}$ and $A M F$ inoculation in pot experiment

The shoot and root biomass as affected by levels of $\mathrm{P}_{2} \mathrm{O}_{5}$ and $\mathrm{AMF}$ inoculation are presented in Table 2. With increasing levels of $\mathrm{P}_{2} \mathrm{O}_{5}$ in the treatments the fresh shoot and root biomass increased significantly with or without AMF inoculation. The result showed, significantly highest fresh shoot (48.92 $\mathrm{g} /$ plant) and root (36.86 g/plant) biomass were recorded in the treatment $\mathrm{T}_{6}$ that received highest amount of $\mathrm{P}_{2} \mathrm{O}_{5}(40 \mathrm{~kg} / \mathrm{ha})$ under AMF inoculation. The treatment $\mathrm{T}_{5}$ received only $50 \%$ of $\mathrm{P}_{2} \mathrm{O}_{5}$ could produce comparable fresh shoot (41.81 g/plant) and root (31.21 g/plant) biomass with that of treatment $\mathrm{T}_{6}$. However, the fresh shoot (44.15 g/plant) and root (28.92 $\mathrm{g} /$ plant) biomass in the treatment $\mathrm{T}_{3}$ without AMF inoculation were comparable with the treatments $T_{5}$ and $T_{6}$. With reference to the dry matter, significantly highest shoot (18.93 $\mathrm{g} /$ plant) and root (14.94 g/plant) biomass were recorded in treatment $T_{6}$ followed by 17.61 $\mathrm{g} /$ plant and $12.03 \mathrm{~g} /$ plant in $\mathrm{T}_{3}$ with and without $\mathrm{AMF}$ inoculation respectively. By reducing the $\mathrm{P}_{2} \mathrm{O}_{5}(20 \mathrm{~kg} / \mathrm{ha})$ in treatment $\mathrm{T}_{5}$, the AMF inoculation however produced comparable shoot (16.25 g/plant) and root (13.48 g/plant) dry biomass with that of treatment $\mathrm{T}_{3}$.

Phosphorus and Nitrogen concentration and their uptake in rice plants as influenced by levels of $\mathrm{P}_{2} \mathrm{O}_{5}$ and $\mathrm{AMF}$ inoculation in pot experiment

The phosphorus (P) and nitrogen (N) concentration and their uptake in rice plant as influenced by levels of $\mathrm{P}_{2} \mathrm{O}_{5}$ and $\mathrm{AMF}$ inoculation are depicted in Figure 1 and 2 respectively. It was observed that with increasing levels of $\mathrm{P}_{2} \mathrm{O}_{5}$ both the $\mathrm{P}$ and $\mathrm{N}$ concentrations and their uptake were increased, but the magnitudes were more under AMF inoculation. Significantly highest concentration of $\mathrm{P}(1.33 \mathrm{mg} / \mathrm{g})$ and $\mathrm{N}(8.25$ $\mathrm{mg} / \mathrm{g}$ ) were recorded in the treatment $\mathrm{T}_{6}$ that received highest amount of $\mathrm{P}_{2} \mathrm{O}_{5}(40 \mathrm{~kg} / \mathrm{ha})$ and $\mathrm{AMF}$ inoculation compared to the treatments $T_{1}, T_{2}$ and $T_{4}$ Figure 1. Similarly, in treatment $\mathrm{T}_{3}$, under highest $\mathrm{P}_{2} \mathrm{O}_{5}$ application (40 kg/ha) could increase the $\mathrm{P}$ $(1.28 \mathrm{mg} / \mathrm{g})$ and $\mathrm{N}(7.98 \mathrm{mg} / \mathrm{g})$ concentration which were at par with treatment $\mathrm{T}_{6}$, but without AMF inoculation. But in the treatment $\mathrm{T}_{5}$, by slashing the $\mathrm{P}_{2} \mathrm{O}_{5}(20 \mathrm{~kg} / \mathrm{ha})$ application under AMF inoculation, statistically comparable $\mathrm{P}(1.27 \mathrm{mg} / \mathrm{g})$ and $\mathrm{N}(7.88 \mathrm{mg} / \mathrm{g})$ concentrations were obtained with that of treatments $T_{3}$ and $T_{6}$. Similar trends were observed in case of $\mathrm{P}$ and $\mathrm{N}$ uptake in rice plants. Under AMF inoculation and highest 
application of $\mathrm{P}_{2} \mathrm{O}_{5}(40 \mathrm{~kg} / \mathrm{ha})$, the uptake of $\mathrm{P}$ (25.17 mg/plant) and $\mathrm{N}$ (155.06 mg/plant) in the treatment $\mathrm{T}_{6}$ was significantly highest compared to the treatments $\mathrm{T}_{1}, \mathrm{~T}_{2}, \mathrm{~T}_{4}$ and $\mathrm{T}_{5}$ Figure 2. In the treatment $\mathrm{T}_{3}$, though no AMF inoculation, under highest amount of $\mathrm{P}_{2} \mathrm{O}_{5}(40$ $\mathrm{kg} / \mathrm{ha})$ application the uptake of $\mathrm{P}(22.61$ $\mathrm{mg} /$ plant) and $\mathrm{N}$ (140.64 mg/plant) were at par with the treatment $\mathrm{T}_{6}$. However, by reducing the $\mathrm{P}_{2} \mathrm{O}_{5}(20 \mathrm{~kg} / \mathrm{ha})$ under AMF inoculation in the treatment T5, the uptake of P (20.63 $\mathrm{mg} /$ plant $)$ and $\mathrm{N}(127.50 \mathrm{mg} /$ plant $)$ were remain at par with the treatment $\mathrm{T}_{3}$.

Spore abundance, root colonization, available $\mathrm{P}_{2} \mathrm{O}_{5}$ and phosphomonoesterase activity as influenced by levels of $\mathrm{P}_{2} \mathrm{O}_{5}$ and $\mathrm{AMF}$ inoculation in pot experiment

The AMF spore counts and root colonization as affected by levels of $\mathrm{P}_{2} \mathrm{O}_{5}$ with and without $\mathrm{AMF}$ inoculation in the pot experiment are presented in Table 3.

In the experiment, significantly highest AMF spore counts of $487.50 / 100 \mathrm{~g}$ soil were observed in the treatment $\mathrm{T}_{5}$ that received 50 $\%$ of $\mathrm{P}_{2} \mathrm{O}_{5}(20 \mathrm{~kg} / \mathrm{ha})$ with $\mathrm{AMF}$ inoculation. The treatment $\mathrm{T}_{6}$ that received highest amount of $\mathrm{P}_{2} \mathrm{O}_{5}(40 \mathrm{~kg} / \mathrm{ha})$ could produce AMF spore of $225.00 / 100 \mathrm{~g}$ soil even under AMF inoculation. Under lowest level of $\mathrm{P}_{2} \mathrm{O}_{5}(0$ $\mathrm{kg} / \mathrm{ha}$ ), the inoculation of AMF spore produces significant numbers of AMF spore (379.75/100g soil) in treatment $\mathrm{T}_{4}$ compared to the non inoculated treatments $\left(\mathrm{T}_{1}, \mathrm{~T}_{2}\right.$ and $\mathrm{T}_{3}$ ).

Similarly, the root colonization were also found to be significantly higher in the treatments $\mathrm{T}_{5}(56.57 \%)$ and $\mathrm{T}_{4}(47.50 \%)$ under medium $(20 \mathrm{~kg} / \mathrm{ha})$ and lowest $(0 \mathrm{~kg} / \mathrm{ha})$ levels of $\mathrm{P}_{2} \mathrm{O}_{5}$ application respectively with AMF inoculation compared to non inoculation counterparts $\left(\mathrm{T}_{2}\right.$ and $\left.\mathrm{T}_{1}\right)$. At highest level (40 $\mathrm{kg} / \mathrm{ha}$ ) of $\mathrm{P}_{2} \mathrm{O}_{5}$ application no significant differences of root colonization in the rice root was observed in the treatments $\mathrm{T}_{3}(20.62 \%)$ and $\mathrm{T}_{6}(25.88 \%)$ though the treatment $\mathrm{T}_{6}$ received $\mathrm{AMF}$ inoculation.

The available $\mathrm{P}_{2} \mathrm{O}_{5}$ content in the rhizosphere soil of rice plants were increased with increasing levels of $\mathrm{P}_{2} \mathrm{O}_{5}$ application. Significantly higher amount of available $\mathrm{P}_{2} \mathrm{O}_{5}$ was observed in the treatments $\mathrm{T}_{3}(12.20 \mathrm{ppm})$ and $\mathrm{T}_{6}(11.02 \mathrm{ppm})$ compared to the treatments $\mathrm{T}_{2}(9.36 \mathrm{ppm})$ and $\mathrm{T}_{5}(9.17 \mathrm{ppm})$ that received $40 \mathrm{~kg} / \mathrm{ha}$ and $20 \mathrm{~kg} / \mathrm{ha}$ of $\mathrm{P}_{2} \mathrm{O}_{5}$ application correspondingly.

The phosphomonoesterase (PHM) activity in the rice rhizosphere was also influenced by application of different levels of $\mathrm{P}_{2} \mathrm{O}_{5}$.

In the present investigation, with increasing levels of $\mathrm{P}_{2} \mathrm{O}_{5}$ application the PHM also appeared to increase and significantly higher amount of PHM were observed in the treatment $\mathrm{T}_{3}(274.62 \mu \mathrm{g} p$ nitrophenol $/ \mathrm{g} / \mathrm{h})$ and $\mathrm{T}_{6} \quad(280.74 \quad \mu \mathrm{g} \quad p \quad$ nitrophenol $/ \mathrm{g} / \mathrm{h})$ compared to the treatments $\mathrm{T}_{1}(185.91 \mu \mathrm{g} p$ nitrophenol $/ \mathrm{g} / \mathrm{h})$ and $\mathrm{T}_{4} \quad(195.55 \mu \mathrm{g} \quad p$ nitrophenol/g/h) respectively.

The linear regression line drawn between the PHM activities and available $\mathrm{P}_{2} \mathrm{O}_{5}$ in the rice rhizosphere $\left[\mathrm{y}=0.028 \mathrm{x}+2.912\left(\mathrm{R}^{2}=0.452\right)\right]$ however displayed the significant positive correlation ( $\left.\mathrm{r}=0.673^{* *}, \mathrm{n}=18\right)(\mathrm{Fig} .3)$.

Shoot and root biomass as influenced by levels of $\mathrm{P}_{2} \mathrm{O}_{5}$ and $A M F$ inoculation in pot experiment

The results illustrated that there were no detectable differences $(P<0.05)$ between AMF inoculation $\left(\mathrm{T}_{6}\right)$ and without inoculation $\left(\mathrm{T}_{3}\right)$ treatments at $40 \mathrm{~kg} \mathrm{P}_{2} \mathrm{O}_{5} /$ ha level of $\mathrm{P}$ supply in fresh and dry shoot and root fresh weight of rice, although, in general, all increased with increasing P supply up to $40 \mathrm{~kg}$ $\mathrm{P}_{2} \mathrm{O}_{5} /$ ha. 
Table.1 Initial status of soil chemical and biological parameters

\begin{tabular}{|l|l|l|l|l|l|}
\hline OC\% & Ph & Av. N & $\begin{array}{c}\text { Av. } \mathrm{P}_{2} \mathrm{O}_{5} \\
(\mathrm{ppm})\end{array}$ & Av. $\mathrm{K}_{2} \mathrm{O}$ & $\begin{array}{c}\text { Phosphomonoesterase }(\mu \mathrm{g} p- \\
\text { nitrophenol/g/h) }\end{array}$ \\
\hline $\mathbf{0 . 8 6}$ & 5.20 & 150.32 & 8.45 & 103.12 & 178.25 \\
\hline
\end{tabular}

Table.2 Effect of levels of $\mathrm{P}_{2} \mathrm{O}_{5}$ and AMF inoculation on shoots and root biomass

\begin{tabular}{|c|c|c|c|c|}
\hline \multirow[t]{2}{*}{ Treatments } & Shoot & Root & Shoot & Root \\
\hline & \multicolumn{2}{|c|}{ Fresh weight(gm/plant) } & \multicolumn{2}{|c|}{ Dry weight (gm/plant) } \\
\hline$T_{1}: M_{0} N_{40} P_{0} K_{20}$ & 20.97 & 12.99 & 7.85 & 6.15 \\
\hline $\mathbf{T}_{2}: \mathbf{M}_{0} \mathbf{N}_{40} \mathbf{P}_{20} \mathbf{K}_{20}$ & 30.18 & 17.39 & 12.95 & 8.71 \\
\hline$T_{3}: M_{0} N_{40} P_{40} K_{20}$ & 44.15 & 28.92 & 17.61 & 12.03 \\
\hline $\mathbf{T}_{4}: \mathrm{M}_{1} \mathbf{N}_{40} \mathbf{P}_{0} \mathbf{K}_{20}$ & 23.08 & 15.81 & 10.49 & 7.81 \\
\hline$T_{5}: \mathbf{M}_{1} \mathbf{N}_{40} \mathbf{P}_{20} K_{20}$ & 41.81 & 31.21 & 16.25 & 13.48 \\
\hline$T_{6}: M_{1} N_{40} P_{40} K_{20}$ & 48.92 & 36.86 & 18.93 & 14.94 \\
\hline $\mathrm{CD}(0.05)$ & 6.31 & 4.41 & 2.54 & 1.97 \\
\hline $\mathrm{CV} \%$ & 12.19 & 12.45 & 12.21 & 12.63 \\
\hline
\end{tabular}

Table.3 AMF Spore, root colonization, available $\mathrm{P}_{2} \mathrm{O}_{5}$ and phosphomonoesterase activity as influenced by AMF inoculation

\begin{tabular}{|l|c|c|c|c|}
\hline Treatments & $\begin{array}{c}\text { AMF } \\
\text { Spore/100g soil }\end{array}$ & $\begin{array}{c}\text { Root } \\
\text { Colonization } \\
(\%)\end{array}$ & $\begin{array}{c}\text { Av. } \mathrm{P}_{2} \mathrm{O}_{5} \\
(\mathrm{ppm})\end{array}$ & $\begin{array}{c}\text { Phosphomonoesterase } \\
\text { activity } \\
\text { nitrophenol/g/h } / \mathrm{g} p\end{array}$ \\
\hline $\mathbf{T}_{\mathbf{1}}: \mathbf{M}_{\mathbf{0}} \mathbf{N}_{\mathbf{4 0}} \mathbf{P}_{\mathbf{0}} \mathbf{K}_{\mathbf{2 0}}$ & 93.75 & 18.6 & 7.25 & 185.91 \\
\hline $\mathbf{T}_{\mathbf{2}}: \mathbf{M 0 N}_{\mathbf{4 0}} \mathbf{P}_{\mathbf{2 0}} \mathbf{K}_{\mathbf{2 0}}$ & 96.75 & 18.50 & 9.36 & 190.01 \\
\hline $\mathbf{T}_{\mathbf{3}}: \mathbf{M}_{\mathbf{0}} \mathbf{N}_{\mathbf{4 0}} \mathbf{P}_{\mathbf{4} 0} \mathbf{K}_{\mathbf{2 0}}$ & 84.00 & 20.62 & 12.20 & 274.62 \\
\hline $\mathbf{T}_{\mathbf{4}}: \mathbf{M}_{\mathbf{1}} \mathbf{N}_{\mathbf{4 0}} \mathbf{P}_{\mathbf{0}} \mathbf{K}_{\mathbf{2 0}}$ & 379.75 & 47.50 & 8.16 & 195.55 \\
\hline $\mathbf{T}_{\mathbf{5}}: \mathbf{M}_{\mathbf{1}} \mathbf{N}_{\mathbf{4 0}} \mathbf{P}_{\mathbf{2 0}} \mathbf{K}_{\mathbf{2 0}}$ & 487.50 & 56.57 & 9.17 & 258.07 \\
\hline $\mathbf{T}_{\mathbf{6}}: \mathbf{M}_{\mathbf{1}} \mathbf{N}_{\mathbf{4 0}} \mathbf{P}_{\mathbf{4 0}} \mathbf{K}_{\mathbf{2 0}}$ & 225.00 & 25.88 & 11.02 & 280.74 \\
\hline $\mathrm{CD}(0.05)$ & $\mathbf{4 7 . 9 0}$ & $\mathbf{5 . 7 5}$ & $\mathbf{1 . 9 4}$ & $\mathbf{4 0 . 0 4}$ \\
\hline $\mathrm{CV} \%$ & $\mathbf{1 4 . 1 5}$ & $\mathbf{1 2 . 3 8}$ & $\mathbf{1 3 . 7 1}$ & $\mathbf{1 1 . 6 8}$ \\
\hline
\end{tabular}


Fig.1 Phosphorus $(\mathrm{P})$ and nitrogen $(\mathrm{N})$ concentration in rice plants as influenced by levels of $\mathrm{P}_{2} \mathrm{O}_{5}$ and $\mathrm{AMF}$ inoculation

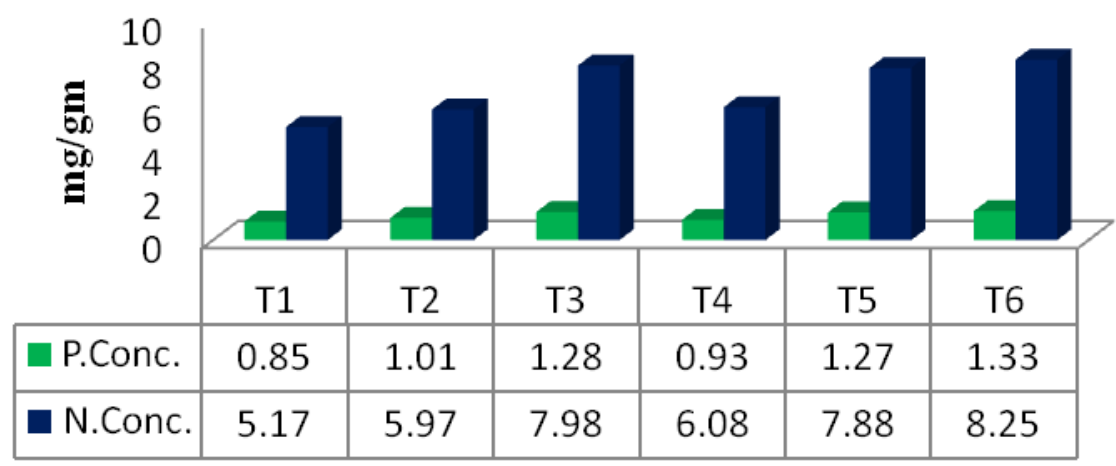

Fig.2 Phosphorus $(\mathrm{P})$ and nitrogen $(\mathrm{N})$ uptake in rice plants as influenced by levels of $\mathrm{P}_{2} \mathrm{O}_{5}$ and AMF inoculation

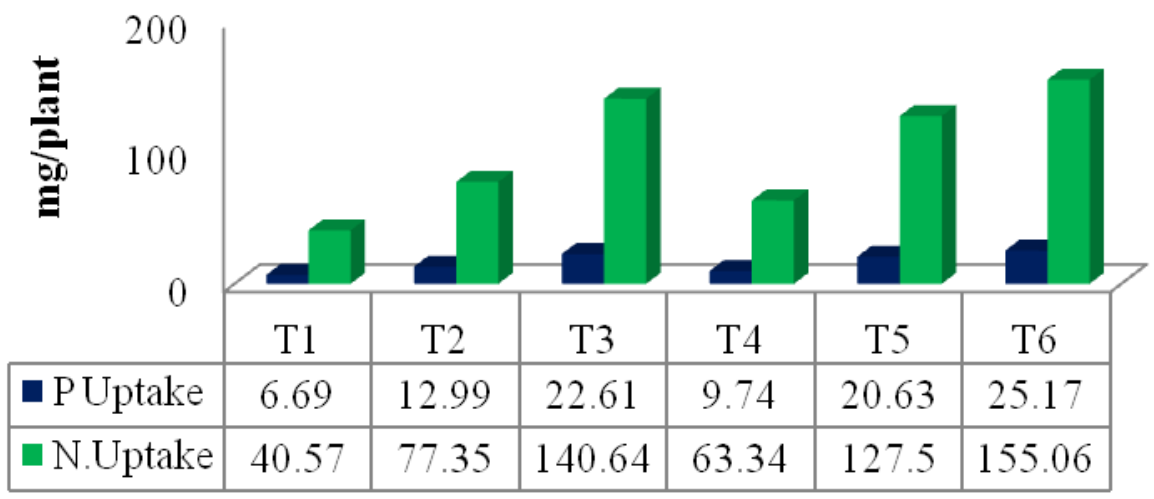

Fig.3 Relationship between available $\mathrm{P}_{2} \mathrm{O}_{5}$ and phosphomonoesterase activity in rice rhizosphere

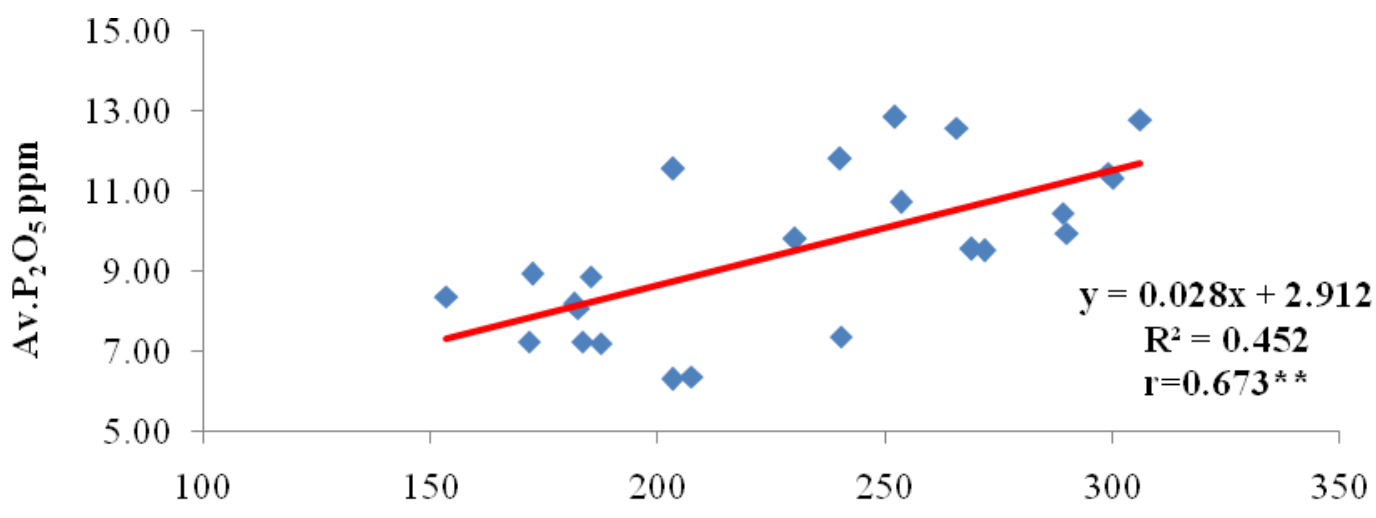

Phosphomonoesterase activity ( $\mu$ pnitrophenol/g/h) 
However, significantly comparable results $(P$ $<0.05)$ for fresh and dry weight of shoot and root of rice $\left(\mathrm{T}_{6}\right.$ and $\left.\mathrm{T}_{3}\right)$ were obtained by reducing the levels $\mathrm{P}_{2} \mathrm{O}_{5}$ of up to $50 \%$ (20 $\mathrm{kg} / \mathrm{ha}$ ) in the treatment $\mathrm{T}_{5}$ under AMF inoculation (Table 2). The distinctions in biomass (shoot and root) became evident 60 days following submergence and by the end un-inoculated plants $\left(\mathrm{T}_{3}\right)$ were similar with inoculated plants $\left(\mathrm{T}_{6}\right)$ at $40 \mathrm{~kg} \quad \mathrm{P}_{2} \mathrm{O}_{5} / \mathrm{ha}$. However, the comparable plant biomass at 20 $\mathrm{kg} \mathrm{P}_{2} \mathrm{O}_{5} /$ ha $\left(\mathrm{T}_{5}\right)$ indicate that AMF have the potential to influence plant morphology in submerged soils and especially in the acidic soils of Assam.

\section{Phosphorus and nitrogen concentration} and their uptake in rice plants as influenced by levels of $\mathrm{P}_{2} \mathrm{O}_{5}$ and $A M F$ inoculation in pot experiment

When assessed in terms of $\mathrm{P}$ and $\mathrm{N}$ concentration and their uptake in rice plants $(P<0.05)$, the presence or absence of AMF did not lead to visible performance at highest level of $\mathrm{P}$ supply $(40 \mathrm{~kg} / \mathrm{ha})$ in the treatments $\mathrm{T}_{6}$ and $\mathrm{T}_{3}$ respectively (Fig. 1 and 2 ). In fact, the only measurable effect of AMF on $\mathrm{P}$ and $\mathrm{N}$ concentration and their uptake in rice plants was obtained by reducing the $\mathrm{P}$ supply by $50 \%(20 \mathrm{~kg} / \mathrm{ha})$ in treatment $\mathrm{T}_{5}$ which were comparable with un-inoculated plants $\left(\mathrm{T}_{3}\right)$ at $40 \mathrm{~kg} \mathrm{P}_{2} \mathrm{O}_{5} /$ ha (Fig. 1 and 2). AMF are naturally active under upland ecology and upland rice has been reported to be benefitted from $\mathrm{AMF}$ for $\mathrm{P}$ acquisition (Maiti et al., $2005,2011)$. In the acidic soils at very low levels of plant-available $\mathrm{P}$, the medium $\mathrm{P}$ fertilization treatment $\left(\mathrm{T}_{5}\right)$ was probably the only treatment with adequate $\mathrm{P}$ supply for AMF dependence, and therefore, improved plant acquisitions of $\mathrm{P}$ and $\mathrm{N}$ was observed in this treatment under submerged situation. Besides improved P nutrition by AMF (Smith and Smith, 2011), it was reported that mycorrhizal plants can transfer $\mathrm{N}$ to the host plants, ranging from 20 to $74 \%$ of the total $\mathrm{N}$ uptake (Tanaka and Yano 2005; Fellbaum et $a l ., 2014$ ) from both inorganic and organic $\mathrm{N}$ sources (Leigh et al., 2009).

Spore abundance, root colonization, available $\mathrm{P}_{2} \mathrm{O}_{5}$ and phosphomonoesterase activity as influenced by levels of $\mathrm{P}_{2} \mathrm{O}_{5}$ and $A M F$ inoculation in pot experiment

AMF spores and root colonization were found at all levels of $\mathrm{P}$ supply, although in general the numbers of AMF spores and percent root colonization decreased with increasing $\mathrm{P}$ under AMF inoculation treatments $\left(\mathrm{T}_{4}, \mathrm{~T}_{5}\right.$ and $\mathrm{T}_{6}$ ) (Table 3). This negative correlation between $\mathrm{P}$ availability and AMF spores and root colonization is well-documented in terrestrial systems (Smith and Read, 2008) and may also prevail in aquatic systems. Since $\mathrm{P}$ availability, is highly dependent on soil water content, the observed reductions in AMF and root colonization in submerged soils may be attributable to increased $\mathrm{P}$ availability rather than a direct result of increased water levels. In the current experiment the availability of $\mathrm{P}$ also significantly $(P<0.05)$ increased with increasing $\mathrm{P}$ supply and was found to be significantly correlated $(\mathrm{r}=0.673 * *)$ with the enzyme PHM (Table 3; Fig. 3). If the opposite were true, and AM colonization levels are dependent on water availability rather than $\mathrm{P}$, colonization levels should remain constant under saturated conditions. This, however, was not the case in the current study and a similar reduction in root colonization levels with increasing $\mathrm{P}$ was found for Lathrum salicaria grown under saturated conditions (Stevens et al., 2002) implies that saturation or inundation does not necessarily prevent the association from developing.

It can be concluded from the present investigation that by reducing the $\mathrm{P}_{2} \mathrm{O}_{5}$ level 
by $50 \%(20 \mathrm{~kg} / \mathrm{ha})$ along with recommended dose of $\mathrm{N}$ and $\mathrm{K}_{2} \mathrm{O}$, the effectiveness of arbuscular mycorrhyzae on enhancing plant biomass and nutrient uptake $(\mathrm{P}$ and $\mathrm{N})$ in rice plant is comparable with the treatments of highest level of phosphatic fertilizer, with or with out the inoculation. Similarly, significantly highest AMF spore counts were observed in the treatment $\mathrm{T}_{5}$ that received 50 $\%$ of $\mathrm{P}_{2} \mathrm{O}_{5}(20 \mathrm{~kg} / \mathrm{ha})$ along with AMF inoculation. Per cent root colonization were significantly higher in the treatments $\mathrm{T}_{5}$ $(56.57 \%)$ and $\mathrm{T}_{4}(47.50 \%)$ under medium $(20 \mathrm{~kg} / \mathrm{ha})$ and lowest $(0 \mathrm{~kg} / \mathrm{ha})$ levels of $\mathrm{P}_{2} \mathrm{O}_{5}$ application respectively with AMF inoculation compared to non inoculation counterparts $\left(\mathrm{T}_{2}\right.$ and $\left.\mathrm{T}_{1}\right)$. Elevated level of Phosphorus in soil does not necessitate high level of mycorrhyzal colonization. This study reveals that AMF works very efficiently under low and medium doses of phosphatic fertilizer in submerged conditions.

\section{References}

Bray, R. H. and Kurtz, L. T. (1956). Determination of total organic and available form of phosphorus in soils. Soil Science. 74 pp.

Fellbaum, C.R., Mensah, J.A., Cloos, A.J., Strahan, G.E., Pfeffer, P.E., Kiers, E.T. and Bucking, H. (2014). Fungal nutrient allocation in common mycorrhizal networks is regulated by the carbon source strength of individual host plants. New Phytologist 203: 646-656.

Gerdemann, J. W. and Nicolson, T. H. (1963). Spores of mycorrhizal Endogone extracted from soil by wet sieving and decanting. Transactions of the British Mycological Society 46: 235-244.

Gomez, K.A. and Gomez, A.A. (1984). Statistical Procedures for Agricultural Research. John Wiley \& Sons, New Delhi.
Hodge, A., Campbell, C.D. and Fitter, A.H. (2001). An arbuscular mycorrhizal fungus accelerates decomposition and acquires nitrogen directly from organic material. Nature 413: 297299.

Jacson, M.L. (1973). In: Soil chemical analysis. Prentice Hall of India. Pvt. Ltd. New Delhi.

Kahiluoto, H., Ketoja, E. and Vestberg, M. (2009). Contribution of mycorrhiza to soil quality in contrasting cropping systems. Agriculture, Ecosystems \& Environment 134: 36-45.

Kjeldahl, J. Z. (1883). A new method for the determination of nitrogen in organic bodies. Analytical Chemistry 22: 366.

Koide, R.T., Goff, M.D., Dickie, I.A. (2000). Component growth efficiencies of mycorrhizal and nonmycorrhizal plants. New Phytologist 148: 163168.

Leigh, J., Hodge, A. and Fitter, A. (2009). Arbuscular mycorrhizal fungi can transfer substantial amounts of nitrogen to their host plant from organic material. New Phytologist 181: 199-207.

Linderman, R.G. (1994). Role of VAM in biocontrol. In: Pfleger, F.L. and Linderman, R.G. (Eds.). Mycorrhizae and Plant Health. APS Press, St. Paul, NM, USA, pp. 1-26.

Maiti, D., Variar, M., Saha, J. (1995). Colonization of upland rice by native VAM under rainfed mono-cropped ecosystem. In: Roy, A.K., Sinha, K.K. (eds) Recent advances in phytopathological research. MD Publications, New Delhi, pp 45-52.

Maiti, D., Variar, M. and Singh, R. K. (2011). Optimizing tillage schedule for maintaining activity of the arbuscular mycorrhizal fungal population in a rainfed upland rice (Oryza sativa L.) agro-ecosystem Mycorrhiza 21: 167- 
171.

Phillips, J.M. and Hayman, D.A. (1970). Improved Procedures for Clearing Roots and Staining Parasitic and Vesicular-Arbuscular Mycorrhizal Fungi for Rapid Assessment of Infection. Transactions of the British Mycological Society 55: 158-161.

Purakayastha, T.J., Chhonkar, P.K. (2001). Influence of vesicular-arbuscular mycorrhizal fungi (Glomus etunicatum L.) on mobilization of $\mathrm{Zn}$ in wetland rice (Oryza sativa L.). Biology and Fertility of Soils 33: 323-327.

Redecker, D., Kodner, R. and Graham, L.E. (2000). Glomalean fungi from the Ordovician. Science 289: 1920-1921.

Schubler, A., Schwarzott, D. and Walker, C. (2001). A new fungal phylum, the Glomeromycota: phylogeny and evolution. Mycological Research 105: 1413-1421.

Smith, F. and Smith, S. (2011). what is the significance of the arbuscular mycorrhizal colonisation of many economically important crop plants? Plant and Soil 348: 663-679.

Smith, S.E. and Read D.J. (2008). Mycorrhizal Symbiosis (third Ed). Academic Press Elsevier, New York.

Solaiman, M.Z. and Hirata, H. (1997). Responses of directly seeded wetland rice to arbuscular mycorrhizal fungi inoculation, Journal of Plant Nutrition. 20:(11) 1479-1487.
Stevens, K.J., Spender, S.W. and Peterson, R.L. (2002). Phosphorus, arbuscular mycorrhizal fungi and performance of the wetland plant Lythrum salicaria $\mathrm{L}$. under inundated conditions Mycorrhiza 12: 277-283.

Sturmer, S.L. (2012). A history of the taxonomy and systematics of arbuscular mycorrhizal fungi belonging to the phylum Glomeromycota. Mycorrhiza 22: 247258.

Tabatabai, M.A. and Brenmer, J.A. (1969). Use of $p$-nitrophenyl phosphate for assay of soil phosphatase activity. Soil Biology and Biochemistry 1: 301-307.

Tanaka, Y. and Yano, K. (2005). Nitrogen delivery to maize via mycorrhizal hyphae depends on the form of $\mathrm{N}$ supplied. Plant, Cell Environment 28: 1247-1254.

Thompson, J.P. (1994). Inoculation with vesicular-arbuscular mycorrhizal fungi from cropped soil overcomes longfallow disorder of linseed (Linum usitatissimum L.) by improving $\mathrm{P}$ and $\mathrm{Zn}$ uptake. Soil Biology and Biochemistry 26: 1133-1143.

Watanabe, F.S. and Olsen, S.R. (1965). Test of an ascorbic acid method for determining phosphorus in water and $\mathrm{NaHCO}_{3}$ extracts from soil. Soil Science Society of America 29: 677678.

\section{How to cite this article:}

Ipsita Ojah, Dhruba Jyoti Nath, Anjuma Gayan and Smrita Buragohain. 2018. Influence of Different Levels of Phosphorus on the Effectiveness of Arbuscular Mycorrhizae in Rice Rhizosphere. Int.J.Curr.Microbiol.App.Sci. 7(07): 1076-1085.

doi: https://doi.org/10.20546/ijcmas.2018.707.131 